\title{
COVID-19 as part of the hyperferritinemic syndromes: the role of iron depletion therapy
}

\author{
Carlo Perricone ${ }^{1}$ (D) Elena Bartoloni ${ }^{1} \cdot$ Roberto Bursi $^{1} \cdot$ Giacomo Cafaro $^{1} \cdot$ Giacomo Maria Guidelli $^{2}$. \\ Yehuda Shoenfeld ${ }^{3,4,5} \cdot$ Roberto Gerli $^{1}$
}

Published online: 17 July 2020

(C) The Author(s) 2020

\begin{abstract}
SARS-CoV-2 infection is characterized by a protean clinical picture that can range from asymptomatic patients to life-threatening conditions. Severe COVID-19 patients often display a severe pulmonary involvement and develop neutrophilia, lymphopenia, and strikingly elevated levels of IL-6. There is an over-exuberant cytokine release with hyperferritinemia leading to the idea that COVID-19 is part of the hyperferritinemic syndrome spectrum. Indeed, very high levels of ferritin can occur in other diseases including hemophagocytic lymphohistiocytosis, macrophage activation syndrome, adult-onset Still's disease, catastrophic antiphospholipid syndrome and septic shock. Numerous studies have demonstrated the immunomodulatory effects of ferritin and its association with mortality and sustained inflammatory process. High levels of free iron are harmful in tissues, especially through the redox damage that can lead to fibrosis. Iron chelation represents a pillar in the treatment of iron overload. In addition, it was proven to have an anti-viral and anti-fibrotic activity. Herein, we analyse the pathogenic role of ferritin and iron during SARS-CoV-2 infection and propose iron depletion therapy as a novel therapeutic approach in the COVID-19 pandemic.
\end{abstract}

Keywords SARS-CoV-2 - COVID-19 • Anti-viral · Iron · Hyperferritinemic · Hemophagocytic lymphohistiocytosis · Macrophage activation syndrome · Adult-onset Still's disease · Catastrophic antiphospholipid syndrome · Iron · Deferoxamine · Iron depletion therapy

\section{Background}

The outbreak of the SARS-CoV-2 virus emerged as a pandemic risk in early 2020. The disease (COVID-19) is mainly characterized by fever, dry cough, fatigue and lung

Roberto Gerli

roberto.gerli@unipg.it

1 Rheumatology, Department of Medicine, University of Perugia, Piazzale Giorgio Menghini, 1, 06129 Perugia, Italy

2 Rheumatology and Clinical Immunology Humanitas Research Hospital, Rozzano, Milan, Italy

3 Zabludowicz Center for Autoimmune Diseases, Sheba Medical Center, Tel-Aviv University, 5265601 Tel-Hashomer, Israel

4 The Mosaic of Autoimmunity Project, Saint Petersburg University, Saint Petersburg, Russia

5 Ministry of Health of the Russian Federation, Sechenov First Moscow State Medical University, Moscow, Russia involvement leading to pneumonia [1]. Despite most cases having a mild behaviour, up to $14 \%$ can be severe with dyspnoea, tachypnea with a respiratory frequency $\geq 30 / \mathrm{min}$, hypoxemia with $\mathrm{SpO} 2 \leq 93 \%$, partial pressure of arterial oxygen to fraction of inspired oxygen ratio $<300$ and/or pulmonary infiltrates involving more than $50 \%$ of lung parenchyma within 24 to $48 \mathrm{~h}$. The disease can be life-threating in 5\% of cases (i.e. respiratory failure, septic shock and/or multiple organ dysfunction or failure) [2].

So far, no specific treatment has been approved and there is an urgent need for an agent that could either lower the rate of patients entering the critical stage and be lifesaving, especially when acute respiratory distress syndrome (ARDS) occurs. The current treatment strategy includes several anti-viral drugs and anti-rheumatic agents such as chloroquine and hydroxychloroquine that have immunomodulant properties as well as may have a direct anti-viral activity. Nonetheless, a typical hallmark of the disease seems to be a proinflammatory condition with markedly high levels of interleukin (IL)-1B, IL-1RA and tumour necrosis factor (TNF)- $\alpha$ in the early phase and higher levels of IL-2, IL-10 and TNF- $\alpha$ in 
intensive-care-unit patients. Critically ill patients usually develop neutrophilia, lymphopenia and strikingly elevated levels of IL-6 [3].

Indeed, such over-exuberant cytokine release (aka "cytokine storm") $[4,5]$ has been already described in SARS-CoV and MERS-CoV pneumonia suggesting that viral load precedes the peak of IL-6 concentration and subsequent radiographic severity [6]. SARS-CoV-2 enters the pulmonary and intestinal cells through the angiotensin-converting enzyme II (ACE2) to infect them $[7,8]$. The result of this excessive cytokine release is the infiltration of activated neutrophils into the alveolar space and a fibroproliferative stage leading to interstitial fibrosis $[9,10]$. Cytokine release syndrome (CRS) in coronaviruses infection has different causes that have been exemplified by two main mechanisms. The first one is a delayed interferon (IFN) response mediated by multiple structural and non-structural proteins harboured by both SARS-CoV and MERS-CoV that antagonize IFN. The delayed IFN signalling further orchestrates immune responses and sensitizes $\mathrm{T}$ cells to apoptosis. The other is the accumulation of inflammatory monocyte-macrophages and neutrophils in the lungs following human coronaviruses infection as demonstrated in both human and animal studies. These cells are the predominant source of cytokines and chemokines associated with the fatal outcome [11]. On these bases, targeted anticytokine treatment has been proposed and, in some cases, used successfully. Tocilizumab is a monoclonal antibody directed against an IL-6 receptor. It was developed to treat rheumatoid arthritis (RA) patients as well as CRS as a possible consequence of the administration of chimeric-antigen-receptor-engineered $\mathrm{T}$ cell (CAR-T) immunotherapy $[12,13]$. Trials to test the efficacy of tocilizumab on severe COVID-19 patients are being carried out in China and Italy [14] (https://www.aifa.gov.it/ sperimentazioni-cliniche-covid-19).

Nonetheless, the identification and treatment of hyperinflammation are mandatory. Mehta et al. [15] have recently proposed that COVID-19 can be part of the broader spectrum of hyperinflammatory syndromes characterized by CRS, such as the secondary haemophagocytic lymphohistiocytosis (sHLH) [16]. Notably, one of the cardinal features of these syndromes is hyperferritinemia. Significantly higher ferritin characterizes COVID-19 severity and worse prognosis suggesting that mortality might be due to virally driven hyperinflammation [17]. Circulating ferritin levels may not only reflect an acute phase response but rather play a critical role in inflammation [18]. If moderate levels of hyperferritinemia are associated with autoimmune diseases, including systemic lupus erythematosus, RA, multiple sclerosis and antiphospholipid syndrome (APS) [19-22], typically elevated levels are described in other conditions including macrophage activation syndrome (MAS), adultonset Still's disease (AOSD), catastrophic APS (cAPS) and septic shock. In critically ill patients, hyperferritinemia is associated with the severity of the underlying disease [23-25]; moreover, extremely high levels of ferritin $(>3000 \mathrm{ng} / \mathrm{ml})$ seem to be associated with increased mortality in a dose-response manner [26]. Such high levels of ferritin seem to distinguish patients with hemophagocytic lymphohistiocytosis from those with sepsis, septic shock and other conditions in intensive care units (ICUs) and a cutoff of ferritin of $9083 \mu \mathrm{g} / \mathrm{L}$ showed high sensitivity and specificity and may contribute to improved diagnosis of hemophagocytic lymphohistiocytosis in ICU settings [27]. It is very intriguing that a viral infection, specifically Chikungunya, was able to induce a hyperferritinemic syndrome with underlying AOSD and cAPS [28].

\section{Hyperferritinemic syndrome}

The hyperferritinemic syndrome pathogenesis is extremely complex and variable. Genetic mutations, infections, underlying diseases and immunosuppression can play a distinct role in these conditions, leading to the unique epilogue that is hyperferritinemia (>500 $\mu \mathrm{g} / \mathrm{L})$ and hyperinflammation [29]. According to Schulert et al. [30], despite the numerous protagonists that can play a role in the development of hyperferritinemic syndrome, they might converge in at least two mechanisms that provoke hyperferritinemia: overactivation of $\mathrm{T}$ lymphocytes and over-activity of IFN- $\gamma$ [30]. Nevertheless, recent evidences described the direct role of the $\mathrm{H}$-chain of ferritin in activating macrophages to increase the secretion of inflammatory cytokines [31].

Several diseases that may present both hyperinflammation and hyperferritinemia have been grouped under this common umbrella named hyperferritinemic syndrome (Table 1). These include MAS, a secondary form of HLH, AOSD, cAPS and septic shock $[32,33]$. Although these conditions are characterized by different pathogenesis and clinical presentation, it is likely that pathogenically elevated levels of ferritin sustain the inflammatory process [32]. High levels of ferritin are not specific to the abovementioned hyperferritinemic syndrome. Indeed, levelling up to $2000 \mu \mathrm{g} / \mathrm{L}$ of ferritin can be found in other conditions such as liver damage and infections, the first being one of the possible clinical manifestations of HLH while the second the most common trigger of secondary HLH [34]. Nonetheless, as abovementioned, very high levels can identify patients with HLH in ICU settings [26, 35].

\section{Hemophagocytic lymphohistiocytosis}

HLH (also called hemophagocytic syndrome - despite this term is now outdated [36]) is a rare but potentially life-threatening aberrant hyperferritinemic condition [29]. In a retrospective analysis, the 30-day mortality from clinical onset was $35 \%$ $(45 / 129)$ in young patients and $58 \%(44 / 76)$ in patients older than 60 years [37]. In adults, the clinical characteristics of HLH include fever, rash, hepatosplenomegaly, lymph node enlargement, potential bleeding diathesis, sepsis-like syndrome with or 
Table 1 The spectrum of hyperferritinemic syndromes: suspected aetiologies, clinical features and therapeutic strategies

Hyperferritinemic syndromes

\begin{tabular}{|c|c|c|c|}
\hline Name & Aetiology & Clinical features & Therapeutic strategy \\
\hline $\begin{array}{l}\text { Secondary haemophagocytic } \\
\text { lymphohistiocytosis }\end{array}$ & $\begin{array}{l}\text { Infections } \\
\text { - Viruses } \\
\text { - Bacteria } \\
\text { - Parasites } \\
\text { - Fungi } \\
\text { Malignancies } \\
\text { - Mainly malignant lymphoma } \\
\text { Autoinflammatory or autoimmune } \\
\quad \text { disorders } \\
\text { Other causes } \\
\text { - Transplantation } \\
\text { - Metabolic } \\
\text { - Traumatic } \\
\text { - Iatrogenic (immunosuppression, } \\
\quad \text { vaccination, surgery, } \\
\text { haemodialysis) } \\
\text { - Pregnancy }\end{array}$ & $\begin{array}{l}\text { Fever, rash, hepatosplenomegaly, } \\
\text { lymph node enlargement, bleeding } \\
\text { diathesis, sepsis-like syndrome, } \\
\text { variable degrees of neurologic } \\
\text { symptoms, possibly rapidly unex- } \\
\text { pected progress to multiple organ } \\
\text { failure }\end{array}$ & $\begin{array}{l}\text { HLH-94 protocol: } \\
\text { - Glucocorticoids } \\
\text { - Cyclosporine A } \\
\text { - Intrathecal therapy } \\
\text { - Etoposide } \\
\text { Treatment of the specific trigger/ } \\
\quad \text { underlying disease: } \\
\text { - Glucocorticoids } \\
\text { - Anti-viral drugs } \\
\text { - Anti-CD20 (rituximab) } \\
\text { - Intravenous immunoglobulins } \\
\text { - Chemotherapy } \\
\text { - IL-1 inhibitors (anakinra, canakinumab) } \\
\text { - IL6 inhibitors (tocilizumab) } \\
\text { Currently being tested: } \\
\text { - JAK1/2 inhibitors (ruxolitinib) } \\
\text { - anti-IFN- } \gamma \text { (alemtuzumab, emapalumab) }\end{array}$ \\
\hline $\begin{array}{l}\text { Catastrophic } \\
\text { antiphospholipid syndrome }\end{array}$ & $\begin{array}{l}\text { Trigger supposed to be infections in } \\
\text { the presence of antiphospholipid } \\
\text { antibodies }\end{array}$ & $\begin{array}{l}\text { Microvascular thrombosis: } \\
\text { renal insufficiency, acute respiratory } \\
\text { distress syndrome/pulmonary } \\
\text { embolism, encephalopathy, stroke, } \\
\text { seizures, headache and coma, heart } \\
\text { failure, myocardial infarction, val- } \\
\text { vular defects, livedo reticularis, skin } \\
\text { necrosis and digital ischemia; } \\
\text { spleen, adrenal glands, pancreas, } \\
\text { retina and bone marrow infarction }\end{array}$ & $\begin{array}{l}\text { Intravenous heparin } \\
\text { Glucocorticoids } \\
\text { Intravenous immunoglobulins } \\
\text { Cyclophosphamide } \\
\text { Anti-CD20 (rituximab) } \\
\text { Plasmapheresis } \\
\text { Eculizumab }\end{array}$ \\
\hline Adult onset Still's disease & $\begin{array}{l}\text { Not clearly defined } \\
\text { - Viruses } \\
\text { - Bacteria } \\
\text { - Solid cancers } \\
\text { - Haematological malignancies }\end{array}$ & $\begin{array}{l}\text { Fever, arthritis, skin rash, myalgias, } \\
\text { splenomegaly, lymphadenopathy, } \\
\text { sore throat, liver involvement, } \\
\text { pleurisy or pericarditis, abdominal } \\
\text { pain, aseptic meningitis, } \\
\text { disseminated intravascular } \\
\text { coagulation, haemolysis }\end{array}$ & $\begin{array}{l}\text { Glucocorticoids } \\
\text { Hydroxychloroquine } \\
\text { Intravenous immunoglobulins } \\
\text { Methotrexate } \\
\text { Cyclosporine } \\
\text { IL-1 inhibitors (anakinra, } \\
\text { canakinumab, rilonacept) } \\
\text { IL-6 inhibitors (tocilizumab) } \\
\text { TNF-inhibitors (infliximab, } \\
\text { etanercept and adalimumab) }\end{array}$ \\
\hline Septic shock & $\begin{array}{l}\text { Infections } \\
\text { - Viruses } \\
\text { - Bacteria } \\
\text { - Parasites } \\
\text { - Fungi }\end{array}$ & $\begin{array}{l}\text { Fever, rash, disseminated intravascular } \\
\text { coagulation, variable degrees of } \\
\text { neurologic symptoms, possibly } \\
\text { rapidly unexpected progress to } \\
\text { multiple organ failure }\end{array}$ & $\begin{array}{l}\text { Broad spectrum antibiotic therapy } \\
\text { Fluid resuscitation } \\
\text { Vasopressors }\end{array}$ \\
\hline
\end{tabular}

without variable degrees of neurologic symptoms and a possibly rapidly unexpected progress to multiple organ failure [38]. Hyperferritinemia, liver dysfunction, cytopenia, hypertriglyceridemia, hypofibrinogenemia, elevated D-dimer and lactate dehydrogenase are frequently observed [29]. Interestingly, in a large single-centre case series, very high levels of ferritin (> $50,000 \mu \mathrm{g} / \mathrm{L})$ correlated with 30-day mortality [39], and the drop in ferritin level due to the treatment could have an important prognostic value [16].

As reported in the 2019 HLH recommendation, primary and secondary HLH, including MAS-HLH, have a common terminal pathway but with different pathogenic roots [36]. The primary or familial form (FHLH) begins at an earlier age and tends to be more aggressive. It is due to different gene mutations (PRF1, UNC13-4, STX11, STXBP2, etc.) that lead to the dysregulation of the inflammasome $[40,41]$ and/or to the reduction in cytotoxic activity of T cytotoxic lymphocytes (CTL) and natural killer cells (NK); degranulation and the control of macrophages or cell apoptosis can be impaired [42, 43]. Cytotoxic deficiency can lead to persistent antigen exposure of lymphocytes, inducing an overproduction of various inflammatory cytokines, in particular IFN- $\gamma$, and consequently to CRS and uncontrolled activation of macrophages [44].

The secondary form (sHLH) can occur in different conditions among which viral infections are amid the most frequent. Other infections include bacterial [45], parasitic and fungal 
$[46,47]$. Solid or blood malignancies represent other possible causes (40 to $70 \%$ of HLH cases in adults) followed by systemic autoinflammation and autoimmune diseases, in which case sHLH is usually named MAS-HLH [48]. Several rheumatologic diseases can develop MAS-HLH, such as systemic lupus erythematosus, RA, Sjögren's syndrome, vasculitis and, most frequently, systemic juvenile idiopathic arthritis (sJIA), AOSD and cAPS. Finally, conditions of acquired immune deficiency occurring, for instance, after organ transplantation are rarer triggers of SHLH [36].

Virus infections are the main cause of sHLH, especially the Epstein Barr virus (EBV) [49], Herpes simplex virus (HSV) and cytomegalovirus (CMV). How these viral agents are able to trigger HLH is not fully understood. It seems that they may suppress CTL and NK cell cytotoxicity, predisposing to the development of HLH. EBV latent membrane protein-1 (LMP1) can transcriptionally inhibit lymphocyte activation molecule (SLAM)-associated protein (SAP) leading to overt $\mathrm{T}$ cell activation and cytokine production, especially IFN $-\gamma$ [50]. Recombinant hemagglutinin (H5) from H5N1, causing agent of avian influenza, may suppress the perforin expression and reduce cytotoxicity of human CTL in vitro. At the same time, it promotes an overproduction of IFN- $\gamma$ that may play an important role in macrophages overactivation, cytokine storm and hemophagocytosis - all features observed in severe H5N1infected patients [51]. In addition, H1N1 influenza, directly infecting NK cells, reduced their number and their activity [52].

Nevertheless, these mechanisms cannot always explain the development of HLH. Infectious triggers are not always identified, and defects in cytotoxic CTL may not be present [44]. In other HLH models, a prominent role seems to be played directly by the innate immune pathways instead of the CTL and NK activity [44] with the production of IL-1 family cytokines, especially IL-18 and IL-33 [30, 53]. Beside the main treatment of HLH based on HLH-94 protocol, consisting corticosteroids, cyclosporine A, intrathecal therapy and etoposide [36, 54], the treatment of the specific trigger is essential because of the vast heterogeneity of the aetiology of HLH in adult patients. Sometimes, the specific treatment of the trigger agent can be able to control the HLH syndrome without the need of the HLH-94 protocol, as in the case of autoimmune diseases including SLE [55]. Interesting trials testing alternative therapeutic approaches have been promoted, such as those incorporating ruxolitinib (JAK1/2 inhibitor; ClinicalTrials.gov identifiers NCT02400463, NCT03795909, NCT03533790), anakinra (IL-1 blockade; NCT02780583), alemtuzumab (NCT02472054) and emapalumab (anti-IFN-g monoclonal antibody; NCT01818492).

\section{Catastrophic antiphospholipid syndrome}

cAPS is characterized by microthromboses involving at least three organs within a week and is a rare but severe complication of APS. It affects about $1 \%$ of APS patients and the mortality rate reaches $36 \%$. Agmon-Levin et al. demonstrated that hyperferritinemia can be found in patients with primary APS and that it correlates with cAPS ( $71 \%$ of cAPS had hyperferritinemia) [56]. Similarly, in SLE patients, hyperferritinemia correlates with thrombocytopenia, the presence of lupus anticoagulant and anti-cardiolipin antibodies, suggesting it could be an early marker for secondary APS [57]. An emerging complication occurring in COVID-19 is coagulopathy and possible thrombotic microangiopathy [58]. A case of COVID-19 and antiphospholipid antibodies with multiple infarcts has been recently described. Interestingly, markedly elevated ferritin was found also in this patient, strikingly reinforcing the connection between infection, coagulopathy and hyperferritinemia [59].

\section{Septic shock}

According to the last International Consensus Definitions for Sepsis and Septic Shock, sepsis is defined as life-threatening organ dysfunction that can be represented by an increase in the Sequential Sepsis-related Organ Failure Assessment score of 2 points or more, caused by a dysregulated host response to infection [60]. Sepsis can be a life-threatening condition and sometimes can have features in common with HLH, such as hyperferritinemia. As reported by the 2019 guidelines of HLH, forms of sepsis characterized by a marked inflammation, but less than a proper form of HLH, may not fulfil the diagnostic criteria of HLH and are described as 'MAS-like'. For this reason, in critically ill patients with a confirmed or presumed case of sepsis, it is important to exclude the diagnosis of HLH [61]. It is important to underline that viremia, as it has been demonstrated for DNAemia due to HSV type 1, human herpesvirus 6, EBV, CMV and adenovirus, was associated with hyperferritinemia and adverse outcome in paediatric severe sepsis [62]. Whether there is a correlation between SARS-CoV-2 replication and ferritinemia would be of great interest.

\section{Ferritin in inflammation and viral diseases}

Ferritin serves to bind iron molecules and to store iron in a biologically available form for vital cellular processes while protecting proteins, lipids and DNA from the potential toxicity of this metal element. It has been shown that ferritin is composed of two isoforms: $\mathrm{H}$ - and L-, differently enriched ferritin is expressed in several tissues [63] and have different implications during inflammation [31]. Ferritin and its subunits light chain ferritin (LHC) and heavy chain ferritin (HFC) showed in vivo and in vitro immunomodulatory effects [64]. For example, HFC in vitro directly binds chemokine receptor 4 (CXCR4) and affects CXCR2-mediated ERK1/2 activation [65]. Despite the acute rise of blood value of ferritin as part of 
the normal systemic response to inflammation, a hyperferritinemic response is associated with a significantly increased mortality in septic patients [24, 27]. Although the main modulator of ferritin levels is iron availability, its synthesis may also be regulated by different inflammatory cytokines such as IL-1 $\beta$ and IL-6 [66, 67]. Indeed, serum ferritin is affected by upregulation of hepcidin whose production, in turn, is stimulated by pro-inflammatory cytokines, particularly IL-6 [68]. Ten Kate et al. found that in patients with AOSD the amount of iron bound to ferritin is significantly lower compared with samples from healthy controls and patients with hemochromatosis; however, the total amount of circulating iron is much higher than in controls. This suggests that in active AOSD the rapid synthesis of ferritin exceeds the rate of iron incorporation in ferritin [69].

Besides ferritin, another aspect to be considered in viral infections is the impact of iron overload. Iron is required for viral replication and other processes including mitochondrial function, ATP generation, DNA/RNA synthesis and repair and cell survival/ferroptosis [70]. For instance, the activity of the helicases of the SARS-CoV for viral replication requires ATP hydrolysis that in turn needs the presence of iron [71]. Iron overload leads to a worse prognosis in $\mathrm{HBV}$ and $\mathrm{HCV}$ viral infections and iron supplementation increases the mortality in HIV patients, irrespectively of the anaemic status [72-75]. It is likely that SARS-CoV-2 requires iron for viral replication and for its functions, and this is among the rationales for iron chelation therapy in COVID-19 [76].

Furthermore, iron has an effect on the regulation of T lymphocyte sensitivity to the IFN- $\gamma /$ STAT1 signalling pathway. Indeed, it is known that the refractoriness of $\mathrm{T}$ cells to the IFN- $\gamma /$ STAT1 pathway has been attributed mainly to downregulation of the IFN- $\gamma \mathrm{R}$ chains, especially IFN- $\gamma \mathrm{R} 2$. In human T lymphocytes, IFN- $\gamma \mathrm{R} 2$ internalization occurs mostly in clathrin-coated pits independently from IFN- $\gamma$ [77]. Iron binds to cytoplasmic iron regulatory protein 1 (IRP1) and IRP2 which, in turn, regulates expression of proteins such as ferritin. In addition, there is a regulatory loop connecting nitric oxide (NO) and iron: on the one hand, NO modulates IRP activity [78, 79], and, on the other hand, iron impairs inducible NO synthase transcription. It was shown that iron is critical to determine IFN- $\gamma \mathrm{R} 2$ internalization thus preventing the activation of the IFN- $\gamma /$ STAT1 pathway in human T cells. Deferoxamine (DFO), a common iron chelator, can induce an upregulation of IFN- $\gamma \mathrm{R} 2$ expression on the cell surface only in activated $\mathrm{T}$ cells that have entered the cell cycle [80]. This can restore $\mathrm{T}$ cell response to SARS-CoV-2 infection in two ways: (a) restoring the sensitivity of $\mathrm{T}$ lymphocytes to IFN- $\gamma$, (b) possibly inhibiting clathrin-mediated SARSCoV-2 cell entry [81].

Nonetheless, Merad and Martin [82] recently addressed the potentially pathological roles of monocytes and macrophages during SARS-CoV-2 infection. Infiltrating macrophages seem to promote acute inflammation and are involved in fibrotic complications observed in patients under mechanical ventilation. NLRP3 inflammasome activation is likely to occur during the infection and viral accessory protein are potent activators of pro-IL- $1 \beta$ gene transcription and protein maturation. Microvascular thrombotic involvement appears to be mediated by activated monocytes through the production of tissue factor and activation of the extrinsic coagulation pathway. Neutrophils recruitment by activated endothelial cells and release of neutrophil extracellular traps (NETs), in turn, further amplify the coagulation process. The early recognition of such a massive inflammatory process resembling that of MASHLH remains a diagnostic challenge and research focused on the potential diagnostic application of specific biomarkers apart from ferritin [83]. Soluble (s) CD163 is the soluble counterpart of the CD163 receptor for the haemoglobinhaptoglobin complex located on M2 macrophage cell membrane and represents a marker of M2 macrophage activation and differentiation. The shedding and quick release of CD163 is induced by several pro-inflammatory stimuli such as TNF- $\alpha$, oxidative stress and lipopolysaccharide and several studies demonstrated the prognostic role of SCD163 in conditions characterized by a high systemic inflammatory burden, like sepsis or acute respiratory distress syndrome requiring mechanical ventilation $[84,85]$. Moreover, convincing evidence supports the potential role of sCD163 as a biomarker of MAS-HLH [86, 87]. In this setting, activated or hemophagocytic $\mathrm{CD} 163+$ macrophages within bone marrow aspirates were demonstrated to precede MAS-HLH development in subjects with sJIA, thus suggesting the pivotal role of macrophage activation in MAS-HLH through the induction of hemophagocytosis and hypercytokinemia [88]. Of note, serum $\mathrm{SCD} 163$ levels are significantly increased in patients with sJIA associated with MAS-HLH in comparison to patients with an active disease without MAS-HLH, in particular at disease onset, follow the clinical course in response to treatment and, of note, correlate with other surrogate biomarkers of systemic inflammatory burden, like sCD125 and ferritin [89]. Similar increases of sCD163 have been depicted in patients with AOSD, in particular in the group with active disease, and levels were similar for patients with sepsis [90]. Interestingly, sCD163 levels positively correlated with ferritin serum levels only in AOSD patients, suggesting a direct involvement of macrophage in ferritin production in these conditions [91]. Moreover, a recent study demonstrated that systemic lupus erythematosus patients with MAS-HLH display significantly higher levels of sCD163 in comparison with patients with other severe disease manifestations like lupus nephritis, autoimmune haemolytic anaemia or immune thrombocytopenia, with sCD163 levels correlating with disease activity [91]. Levels of sCD163 may also serve as markers to differentiate primary HLH and MAS-HLH. In a recent study, the serum levels of sCD163 were markedly increased in patients with 
MAS-HLH as compared with pHLH patients, thus hypothesising that the macrophage activation in MAS-HLH is higher than in pHLH [92]. Thus, in MAS-HLH, the massive IL-1 $\beta$ release triggers a close autocrine loop leading to cytokine storm with dramatic IL-6, IL-18 and ferritin production and, consequently, sCD163 spreading from macrophages. Surely, a deeper understanding of this complex pathogenic pattern related to massive cytokine release may lead to targeted therapies and improved patient prognosis [16].

\section{Iron depletion therapy}

As a consequence of the abovementioned pathogenic scenario linking iron, inflammation and infections, there is the need to find a possible therapeutic strategy to prevent CRS and onset of fibrosis occurring particularly in patients with COVID-19. The progress in understanding the critical role of proinflammatory cytokines in the pathogenesis of other hyperferritinemic syndromes such as MAS-HLH and AOSD has led to pilot the use of anti-cytokine agents, resulting in an increasing number of successful case reports in patients who were unresponsive to conventional treatments [93]. The inhibition of IL-1 (with the use of anakinra and canakinumab) and IL-6 (mainly with tocilizumab) showed a strong efficacy compared with placebo in several cohorts and randomized controlled trials in MAS-HLH and AOSD. In a post hoc analysis of data from MEASURE, a randomized, multicentre, doubleblind, 24-week, phase 3B trial of tocilizumab in RA, authors depicted a rapid decrease of ferritin, hepcidin and haptoglobin following tocilizumab administration. This is consistent with the idea that IL-6 signalling is a common stimulus to the production of these molecules [94, 95]. The anti-IL-6 effect on ferritin could explain part of the emerging successful reports on tocilizumab treatment in SARS-CoV-2 infection.

Nonetheless, the rapidity of the onset of inflammation in the acute phase of SARS-CoV-2 infection may provoke increased ferritin production to permit adequate storage of iron and to deprive the pathogen of iron. If the binding capacity of transferrin in the blood is exceeded, iron may be found in the plasma as non-transferrin bound iron that changes to its redoxactive form termed labile plasma iron (LPI) [96]. LPI correlates with ferritin levels and contributes to the formation of reactive oxygen species (ROS) resulting in tissue damage and subsequent fibrosis [97] (Fig. 1). Thus, a novel approach to COVID-19 treatment can be represented by iron chelation therapy that can interrupt these steps. Iron chelation represents a pillar in the treatment of iron overload due to a wide spectrum of diseases and multiple chelating agents are currently registered and routinely used in clinical practice. Indeed, deferoxamine (DFO) has a direct effect on ferritin since promotes ferritin degradation in lysosomes by inducing autophagy, while both deferiprone and deferasirox are likely to chelate cytosolic iron and iron which is extracted from ferritin prior to ferritin degradation by proteasomes [98] (Fig. 1). Moreover, several studies have been performed on the potential anti-viral effect of iron-chelating therapy. Indeed, iron overload can contribute to HIV replication in vitro by increasing reverse transcriptase activity and reducing the viability of infected $\mathrm{T}$ cells. Iron chelation by DFO has shown beneficial effects on HIV infection [99] probably through multiple mechanisms such as (1) restriction of DNA synthesis through the inhibition of ribonucleotide reductase, which requires iron to exert its enzymatic activity, (2) inhibition of T cell proliferation that is essential for HIV replication, (3) direct toxic effect on viral DNA and RNA via oxidative stress and (4) inhibition of NF$\mathrm{kB}$ pathway. These effects may not be universal for all iron chelating agents. In fact, DFO and deferiprone (DFP) can both inhibit $\mathrm{T}$ cell proliferation and DNA synthesis, while bleomycin can directly bind to viral DNA with no effect on host $\mathrm{T}$ cells $[100,101]$.

A potential anti-viral effect has also been demonstrated with other pathogens, such as HSV-1 [102] and CMV. More specifically, CMV requires iron in order to induce an increase in the size of infected cells, so that increased in vitro levels of free iron have been demonstrated before the occurrence of this phenomenon, which can be effectively limited by iron chelation therapy [103]. DFO is also capable to further enhance the therapeutic effect of IFN on hepatitis B virus (HBV) infection [104]. Fewer data are available on the effect of iron chelation on other infective agents, though Mateos et al. [105] reported increased levels of free iron in the bronchoalveolar lavage (BAL) fluid of HIV patients with Pneumocystis jiroveci pneumonia compared with controls, suggesting a potential pathogenic role of iron. Similarly, a beneficial effect of DFO treatment was demonstrated in a murine model of Trypanosoma cruzi infection, independently from the iron metabolism of the host cell [106]. However, it should be carefully considered that iron chelators may actually be exploited by pathogens as sources of iron [107], thus a careful analysis of the pharmacodynamic mechanisms of the single chelating agents available is warranted.

One of the main mechanisms through which iron can promote inflammation is mediated by increased production of free oxygen radicals via the Haber-Weiss reaction. As an example, iron is able to increase the in vitro production of IL-6 by endothelial cells following infection with Chlamydia pneumoniae and influenza A virus, which can be effectively controlled by DFO [108]. Interestingly, similar processes, including IL-6 and free oxygen radical production, take place during septic shock. Thus, it is not surprising that iron chelation is effective in decreasing mortality in murine models of septic shock via NO scavenging [109] and inhibition of MAP kinases and NF-kB pathways, eventually leading to reduced production of pro-inflammatory cytokines [110]. 


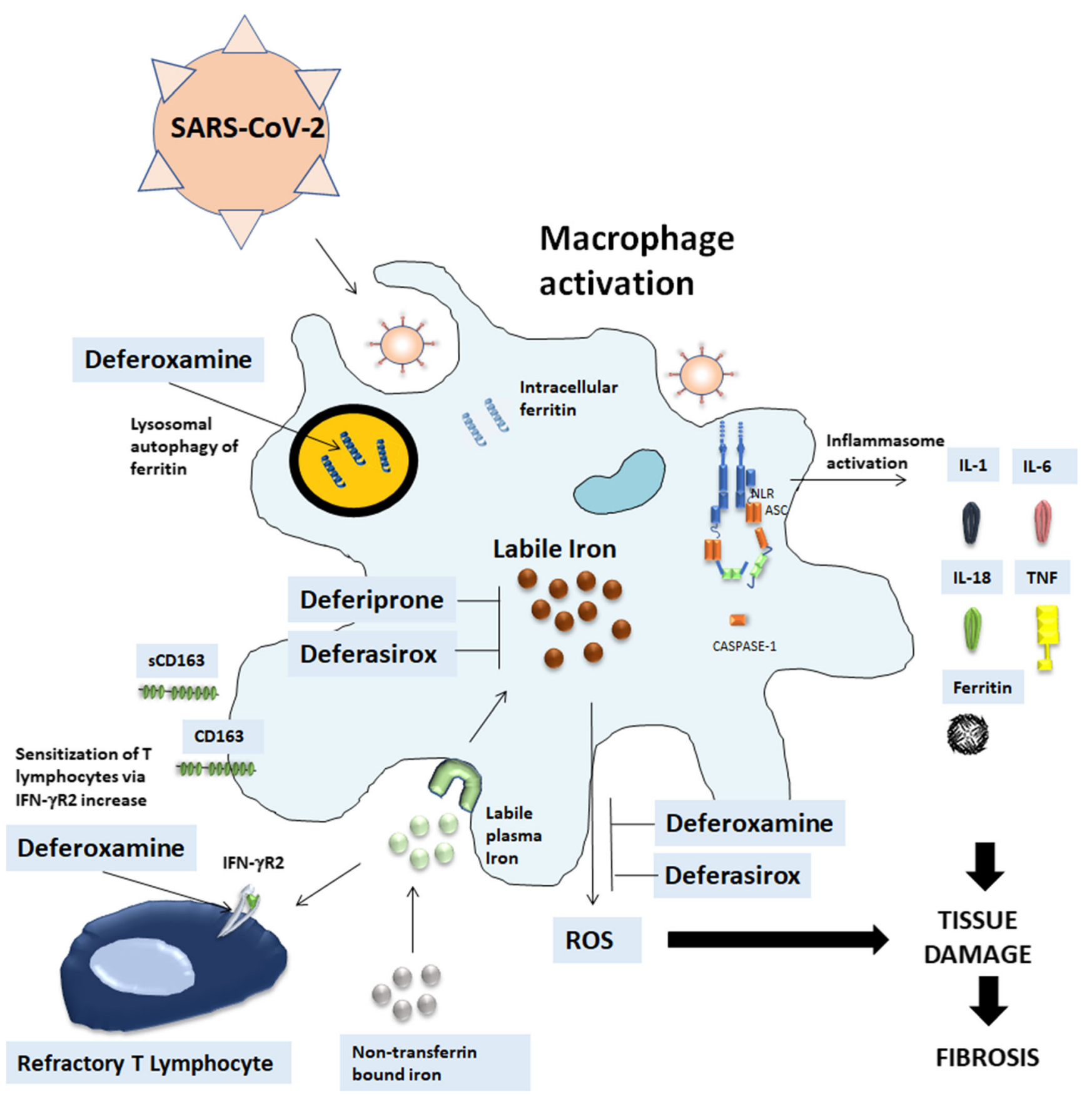

Fig. 1 Iron chelation therapy in SARS-CoV-2 infection. SARS-CoV-2, likely through inflammasome activation, leads to stimulation of infiltrating macrophages that can promote hyperinflammation, characterized by increased levels of IL- 6 , TNF- $\alpha$, IL- $1 \beta$, ferritin and subsequent possible lung fibrotic complications. The increased ferritin production allows adequate storage of iron and deprives the pathogen of iron. Labile iron in the cell contributes to the formation of reactive oxygen species that further promote tissue damage and fibrosis. Iron accumulates in the reticuloendothelial macrophages and the shedding of CD163 is the marker of macrophage activation. Iron chelation therapy can interrupt these steps. (a)

One of the most severe complications of diseases leading to iron overload is liver damage, characterized by progressive fibrosis and, eventually, irreversible cirrhosis. In fact, the
Deferoxamine (DFO) has a direct effect on ferritin since promotes ferritin degradation in lysosomes by inducing autophagy. Both deferiprone and deferasirox are likely to chelate cytosolic iron and iron which is extracted from ferritin prior to ferritin degradation by proteasomes. (b) DFO can induce an up-regulation of IFN- $\gamma \mathrm{R} 2$ expression on the cell surface on activated $\mathrm{T}$ cells thus restoring $\mathrm{T}$ cell response to SARS-CoV-2 infection. (c) Deferasirox and DFO reduce fibrosis-inhibiting the production of free radicals, macrophage tissue infiltration and cause a remarkable decrease of IL-6 levels

prevention of liver damage is the main indication of iron chelation in these conditions. Although the reduction of free iron levels and, consequently, of oxygen radicals, is the main 
mechanism preventing progressive damage, some authors suggested that iron-chelating agents may exert an independent anti-fibrotic effect. This evidence comes from studies showing a reduction of liver fibrosis in the absence of a significant decline in liver iron content [111]. Deferasirox (DFX) and DFO seem able to reduce damage and fibrosis in multiple rat models of concavalin $\mathrm{A}$ and $\mathrm{CCl}_{4}$-induced liver injury by inhibiting the production of free radicals [112-114], though other studies did not confirm this evidence [115]. Anti-fibrotic effects in kidney disease have also been demonstrated in rat and mouse models of renal damage, again via a reduction of oxidative stress, macrophage tissue infiltration and production of pro-fibrotic cytokines such as TGF- $\beta[116,117]$. Other authors showed that DFO can provoke a remarkable decrease in IL-6 levels and have a potent anti-fibrotic effect in HCV infection [114].

\section{Conclusions}

Whether these phenomena share common aspects with COVID-19 is currently not known. It is, however, reasonable to speculate that iron chelation may influence free radicals and pro-inflammatory cytokines production that is strongly involved in the late phase of COVID-19, eventually leading to acute lung injury and ARDS. It has been shown that mechanical ventilation, often required in COVID-19 patients, may induce lung injury that is known to be associated with the release of inflammatory factors, apoptosis, endothelial dysfunction and activation of the coagulation system $[118,119]$. Interestingly, pre-conditioning with DFO showed a lungprotective effect against mechanical ventilation through effective reduction of ROS formation in macrophages and mitochondria in a mouse model [120].

Additionally, preliminary data seem to suggest that residual lung damage may be present in a subset of severe COVID-19 patients following the acute phase of the disease [121]. If these data were to be confirmed, the anti-fibrotic effect of iron chelating agents may represent an additional mechanism of action deserving careful consideration. There are so far two trials to evaluate the efficacy and safety of deferoxamine in patients with COVID-19 (NCT04333550, NCT04361032) either compared with standard treatment or to tocilizumab, results are eagerly awaited.

To conclude, the abovementioned considerations lead to the idea that COVID-19 may be part of the hyperferritinemic syndrome spectrum [122]. Possible iron acute overload caused by rapid synthesis of ferritin exceeding its iron incorporation rate and the beneficial effects of iron chelation therapy on the inflammatory status as well as on the fibrogenesis occurring in the lungs suggest that, in appropriate setting of critically ill patients with COVID-19, iron chelation therapy could be considered to improve survival and overall long-term outcome.
Funding Information. Open access funding provided by Università degli Studi di Perugia within the CRUI-CARE Agreement.

\section{Compliance with ethical standards}

Conflict of interest The authors declare that they have no conflict of interest.

Open Access This article is licensed under a Creative Commons Attribution 4.0 International License, which permits use, sharing, adaptation, distribution and reproduction in any medium or format, as long as you give appropriate credit to the original author(s) and the source, provide a link to the Creative Commons licence, and indicate if changes were made. The images or other third party material in this article are included in the article's Creative Commons licence, unless indicated otherwise in a credit line to the material. If material is not included in the article's Creative Commons licence and your intended use is not permitted by statutory regulation or exceeds the permitted use, you will need to obtain permission directly from the copyright holder. To view a copy of this licence, visit http://creativecommons.org/licenses/by/4.0/.

\section{References}

1. Guan W, Ni Z, Hu Y, Liang WH, Ou CQ, He JX, et al. Clinical characteristics of coronavirus disease 2019 in China. N Engl J Med. 2020. [Online ahead of print]. https://doi.org/10.1056/ NEJMoa2002032.

2. Wang W, Xu Y, Gao R, Lu R, Han K, Wu G, et al. Detection of SARS-CoV-2 in different types of clinical specimens. JAMA. 2020. [Online ahead of print]. https://doi.org/10.1001/jama.2020.378.

3. Zhou F, Yu T, Du R, Fan G, Liu Y, Liu Z, et al. Clinical course and risk factors for mortality of adult inpatients with COVID-19 in Wuhan, China: a retrospective cohort study. Lancet. 2020;395: 1054-62.

4. Wong CK, Lam CW, Wu AK, Ip WK, Lee NL, Chan IH, et al. Plasma inflammatory cytokines and chemokines in severe acute respiratory syndrome. Clin Exp Immunol. 2004;136:95-103.

5. Tisoncik JR, Korth MJ, Simmons CP, Farrar J, Martin TR, Katze MG. Into the eye of the cytokine storm. Microbiol Mol Biol Rev. 2012;76:16-32.

6. Wang WK, Chen SY, Liu IJ, Kao CL, Chen HL, Chiang BL, et al. Severe acute respiratory syndrome research Group of the National Taiwan University College of Medicine/NTU Hospital. Temporal relationship of viral load, ribavirin, interleukin (IL)-6, IL-8, and clinical progression in patients with severe acute respiratory syndrome. Clin Infect Dis. 2004;39:1071-5.

7. Zhou P, Yang XL, Wang XG, Hu B, Zhang L, Zhang W, et al. A pneumonia outbreak associated with a new coronavirus of probable bat origin. Nature. 2020;579:270-3.

8. Letko M, Marzi A, Munster V. Functional assessment of cell entry and receptor usage for SARS-CoV-2 and other lineage B betacoronaviruses. Nat Microbiol. 2020;5:562-9.

9. Conti P, Ronconi G, Caraffa A, Gallenga CE, Ross R, Frydas I, et al. Induction of pro-inflammatory cytokines (IL-1 and IL-6) and lung inflammation by coronavirus-19 (COVI-19 or SARS-CoV-2): antiinflammatory strategies. J Biol Regul Homeost Agents. 2020;34:1.

10. Xu YH, Dong JH, An WM, Lv XY, Yin XP, Zhang JZ, et al. Clinical and computed tomographic imaging features of novel coronavirus pneumonia caused by SARS-CoV-2. J Inf Secur. 2020;80:394 400.

11. Channappanavar R, Perlman S. Pathogenic human coronavirus infections: causes and consequences of cytokine storm and immunopathology. Semin Immunopathol. 2017;39:529-39. 
12. Tanaka T, Kishimoto T. The biology and medical implications of interleukin-6. Cancer Immunol Res. 2014;2:288-94.

13. $\mathrm{Xu} \mathrm{XJ}$, Tang YM. Cytokine release syndrome in cancer immunotherapy with chimeric antigen receptor engineered $\mathrm{T}$ cells. Cancer Lett. 2014;343:172-8.

14. Xiaoling Xu, Mingfeng Han, Tiantian Li, et al. Effective treatment of severe COVID-19 patients with tocilizumab. ChinaXiv: 202003.00026v1; TOCIVID-19.

15. Mehta P, McAuley DF, Brown M, Sanchez E, Tattersall RS, Manson JJ. HLH across speciality collaboration, UK. COVID19: consider cytokine storm syndromes and immunosuppression. Lancet. 2020;395:1033-4.

16. Karakike E, Giamarellos-Bourboulis EJ. Macrophage activationlike syndrome: a distinct entity leading to early death in sepsis. Front Immunol. 2019;10:55.

17. Ruan Q, Yang K, Wang W, Jiang L, Song J. Clinical predictors of mortality due to COVID-19 based on an analysis of data of 150 patients from Wuhan, China. Intensive Care Med. 2020;46:846-8. https://doi.org/10.1007/s00134-020-05991-x.

18. Torti FM, Torti SV. Regulation of ferritin genes and protein. Blood. 2002;99:3505-16.

19. Zandman-Goddard G, Shoenfeld Y. Ferritin in autoimmune diseases. Autoimmun Rev. 2007;6:457-63.

20. Zandman-Goddard G, Orbach H, Agmon-Levin N, Boaz M, Amital H, Szekanecz Z, et al. Hyperferritinemia is associated with serologic antiphospholipid syndrome in SLE patients. Clin Rev Allergy Immunol. 2011;44:23-30.

21. Da Costa R, Szyper-Kravitz M, Szekanecz Z, Csepany T, Danko K, Shapira Y, et al. Ferritin and prolactin levels in multiple sclerosis. Isr Med Assoc J. 2011;13:91-5.

22. Orbach H, Zandman-Goddard G, Amital H, Barak V, Szekanecz $Z$, Szucs G, et al. Novel biomarkers in autoimmune diseases: prolactin, ferritin, vitamin D, and TPA levels in autoimmune diseases. Ann N Y Acad Sci. 2007;1109:385-400.

23. Bennett TD, Hayward KN, Farris RW, Ringold S, Wallace CA, Brogan TV. Very high serum ferritin levels are associated with increased mortality and critical care in pediatric patients. Pediatr Crit Care Med. 2011;12:e233-6.

24. Garcia PC, Longhi F, Branco RG, Piva JP, Lacks D, Tasker RC. Ferritin levels in children with severe sepsis and septic shock. Acta Paediatr. 2007;96:1829-31.

25. Castillo L, Carcillo J. Secondary hemophagocytic lymphohistiocytosis and severe sepsis/ systemic inflammatory response syndrome/multiorgan dysfunction syndrome/macrophage activation syndrome share common intermediate phenotypes on a spectrum of inflammation. Pediatr Crit Care Med. 2009;10:387-92.

26. Grangé S, Buchonnet G, Besnier E, Artaud-Macari E, Beduneau G, Carpentier D, et al. The use of ferritin to identify critically ill patients with secondary hemophagocytic lymphohistiocytosis. Crit Care Med. 2016 Nov;44(11):e1045-53.

27. Lachmann G, Knaak C, Vorderwülbecke G, la Rosée P, Balzer F, Schenk T, et al. Hyperferritinemia in critically ill patients. Crit Care Med. 2020;48(4):459-65.

28. Betancur JF, Navarro EP, Echeverry A, Moncada PA, Cañas CA, Tobón GJ. Hyperferritinemic syndrome: Still's disease and catastrophic antiphospholipid syndrome triggered by fulminant Chikungunya infection: a case report of two patients. Clin Rheumatol. 2015;34:1989-92.

29. Birndt S, Schenk T, Heinevetter B, Brunkhorst FM, Maschmeyer G, Rothmann F, et al. Hemophagocytic lymphohistiocytosis in adults: collaborative analysis of 137 cases of a nationwide German registry. J Cancer Res Clin Oncol. 2020;146:1065-77.
30. Schulert GS, Canna SW. Convergent pathways of the hyperferritinemic syndromes. Int Immunol. 2018;30:195-203.

31. Ruscitti P, Cipriani P, Ciccia F, Di Benedetto P, Liakouli V, Berardicurti O, et al. H-ferritin and CD68(+) /H-ferritin(+) monocytes/macrophages are increased in the skin of adult-onset Still's disease patients and correlate with the multi-visceral involvement of the disease. Clin Exp Immunol. 2016;186:30-8.

32. Rosário C, Zandman-Goddard G, Meyron-Holtz EG, D'Cruz DP, Shoenfeld Y. The hyperferritinemic syndrome: macrophage activation syndrome, Still's disease, septic shock and catastrophic antiphospholipid syndrome. BMC Med. 2013;11:185.

33. Carcillo JA, Simon DW, Podd BS. How we manage hyperferritinemic sepsis-related multiple organ dysfunction syndrome/macrophage activation syndrome/secondary hemophagocytic lymphohistiocytosis histiocytosis. Pediatr Crit Care Med. 2015;16:598-600.

34. Schaffner M, Rosenstein L, Ballas Z, Suneja M. Significance of hyperferritinemia in hospitalized adults. Am J Med Sci. 2017;354: 152-8.

35. Saeed H, Woods RR, Lester J, Herzig R, Gul Z, Monohan G. Evaluating the optimal serum ferritin level to identify hemophagocytic lymphohistiocytosis in the critical care setting. Int J Hematol. 2015;102(2):195-9.

36. La Rosée P, Horne A, Hines M, von Bahr Greenwood T, Machowicz R, Berliner N, et al. Recommendations for the management of hemophagocytic lymphohistiocytosis in adults. Blood. 2019;133:2465-77.

37. Wang H, Xiong L, Tang W, Zhou Y, Li F. A systematic review of malignancy-associated hemophagocytic lymphohistiocytosis that needs more attentions. Oncotarget. 2017;8:59977-85.

38. Danhaive O, Caniglia M, Devito R, Piersigilli F, Corchia C, Auriti C. Neonatal liver failure and haemophagocytic lymphohistiocytosis caused by a new perforin mutation. Acta Paediatr. 2010;99:778-80.

39. Otrock ZK, Eby CS. Clinical characteristics, prognostic factors, and outcomes of adult patients with hemophagocytic lymphohistiocytosis. Am J Hematol. 2015;90:220-4.

40. Romberg N, Vogel TP, Canna SW. NLRC4 inflammasomopathies. Curr Opin Allergy Clin Immunol. 2017;17:398-404.

41. Romberg N, Al Moussawi K, Nelson-Williams C, Stiegler AL, Loring E, Choi M, et al. Mutation of NLRC4 causes a syndrome of enterocolitis and autoinflammation. Nat Genet. 2014;46:1135-9.

42. Sepulveda FE, de Saint Basile G. Hemophagocytic syndrome: primary forms and predisposing conditions. Curr Opin Immunol. 2017;49:20-6.

43. Lehmberg K, Sprekels B, Nichols KE, Woessmann W, Müller I, Suttorp M, et al. Malignancy-associated haemophagocytic lymphohistiocytosis in children and adolescents. Br J Haematol. 2015;170:539-49.

44. Behrens EM, Canna SW, Slade K, Rao S, Kreiger PA, Paessler M, et al. Repeated TLR9 stimulation results in macrophage activation syndrome-like disease in mice. J Clin Invest. 2011;121:2264-77.

45. Choi YB, Yi DY. Fatal case of hemophagocytic lymphohistiocytosis associated with group B streptococcus sepsis: a case report. Medicine (Baltimore). 2018;97:e12210.

46. Sağlam B, Albayrak M, Acar A, Yıldız A, Maral S, Tı̆̆glığlu M, et al. Q fever as a rare cause of hemophagocytic lymphohistiocytosis: case report. Transfus Apher Sci. 2020;28:102747.

47. Miyoshi Y, Yoshioka S, Gosho H, Miyazoe S, Suenaga H, Aoki $\mathrm{M}$, et al. A neonatal case of coxsackievirus B3 vertical infection with symptoms of hemophagocytic lymphohistiocytosis. ID Cases. 2020;20:e0738. 
48. Gavand PE, Serio I, Arnaud L, Costedoat-Chalumeau N, Carvelli $\mathrm{J}$, Dossier A, et al. Clinical spectrum and therapeutic management of systemic lupus erythematosus-associated macrophage activation syndrome: a study of 103 episodes in 89 adult patients. Autoimmun Rev. 2017;16:743-9.

49. Mărginean MO, Molnar E, Chinceșan MI. Epstein-Barr virus-associated hemophagocytic lymphohistiocytosis in a small child: a case report. Medicine (Baltimore). 2020;99:e18759.

50. Chuang HC, Lay JD, Hsieh WC, Wang HC, Chang Y, Chuang SE, et al. Epstein-Barr virus LMP1 inhibits the expression of SAP gene and upregulates Th1 cytokines in the pathogenesis of hemophagocytic syndrome. Blood. 2005;106:3090-6.

51. Hsieh YC, Wu TZ, Liu DP, Shao PL, Chang LY, Lu CY, et al. Influenza pandemics: past, present and future. J Formos Med Assoc. 2006;105:1-6.

52. Mao H, Liu Y, Sia SF, Peiris JSM, Lau YL, Tu W. Avian influenza virus directly infects human natural killer cells and inhibits cell activity. Virol Sin. 2017;32:122-9.

53. Brisse E, Wouters CH, Andrei G, Matthys P. How viruses contribute to the pathogenesis of hemophagocytic lymphohistiocytosis. Front Immunol. 2017;8:1102.

54. Bergsten E, Horne A, Aricó M, Astigarraga I, Egeler RM, Filipovich AH, et al. Confirmed efficacy of etoposide and dexamethasone in HLH treatment: long-term results of the cooperative HLH-2004 study. Blood. 2017;130:2728-38.

55. Gauiran DTV, Cheng PVCY, Pagaduan CRP, Santos MCM. Autoimmune-associated hemophagocytosis and myelofibrosis in a newly diagnosed lupus patient: case report and literature review. Case Rep Hematol. 2019;2019:3879148.

56. Agmon-Levin N, Rosário C, Katz BS, Zandman-Goddard G, Meroni P, Cervera R, et al. Ferritin in the antiphospholipid syndrome and its catastrophic variant (cAPS). Lupus. 2013;22:1327-35.

57. Zandman-Goddard G, Orbach H, Agmon-Levin N, Boaz M, Amital H, Szekanecz Z, et al. Hyperferritinemia is associated with serologic antiphospholipid syndrome in SLE patients. Clin Rev Allergy Immunol. 2013;44:23-30.

58. Campbell CM, Kahwash R. Will complement inhibition be the new target in treating COVID-19 related systemic thrombosis? Circulation 2020; [Online ahead of print]. https://doi.org/10.1161/ CIRCULATIONAHA.120.047419.

59. Zhang Y, Xiao M, Zhang S, Xia P, Cao W, Jiang W, et al. Coagulopathy and antiphospholipid antibodies in patients with Covid-19. N Engl J Med 2020;[Online ahead of print]. https:// doi.org/10.1056/NEJMc2007575.

60. Singer M. The new sepsis consensus definitions (Sepsis-3): the good, the not-so-bad, and the actually-quite-pretty. Intensive Care Med. 2016;42:2027-9.

61. Knaak C, Schuster FS, Spies C, Vorderwülbecke G, Nyvlt P, Schenk T, et al. Hemophagocytic lymphohistiocytosis in critically ill patients. Shock. 2020;53(6):701-9.

62. Simon DW, Halstead ES, Davila S, Kernan KF, Clark RSB, Storch G, et al. DNA viremia is associated with hyperferritinemia in pediatric sepsis. J Pediatr. 2019;213:82-87.e2. https://doi.org/ 10.1016/j.jpeds.2019.06.033.

63. Ruscitti P, Cipriani P, Di Benedetto P, Liakouli V, Berardicurti O, Carubbi $\mathrm{F}$, et al. H-ferritin and proinflammatory cytokines are increased in the bone marrow of patients affected by macrophage activation syndrome. Clin Exp Immunol. 2018;191:220-8.

64. Ruddell RG, Hoang-Le D, Barwood JM, Rutherford PS, Piva TJ, Watters DJ, et al. Ferritin functions as a proinflammatory cytokine via iron-independent protein kinase $\mathrm{C}$ zeta/nuclear factor kappaBregulated signaling in rat hepatic stellate cells. Hepatology. 2009;49:887-900.
65. Li R, Luo C, Mines M, Zhang J, Fan GH. Chemokine CXCL12 induces binding of ferritin heavy chain to the chemokine receptor CXCR4, alters CXCR4 signaling, and induces phosphorylation and nuclear translocation of ferritin heavy chain. J Biol Chem. 2006;281:37616-27.

66. Recalcati S, Invernizzi P, Arosio P, Cairo G. New functions for an iron storage protein: the role of ferritin in immunity and autoimmunity. J Autoimmun. 2008;30:84-9.

67. Wang W, Knovich MA, Coffman LG, Torti FM, Torti SV. Serum ferritin: past, present and future. Biochim Biophys Acta. 1800;2010:760-9.

68. Camaschella C, Nai A, Silvestri L. Iron metabolism and iron disorders revisited in the hepcidin era. Haematologica. 2020;105:260-72.

69. ten Kate J, Drenth JP, Kahn MF, van Deursen C. Iron saturation of serum ferritin in patients with adult onset Still's disease. J Rheumatol. 2001;28:2213-5.

70. Khodour Y, Kaguni LS, Stiban J. Iron-sulfur clusters in nucleic acid metabolism: varying roles of ancient cofactors. Enzymes. 2019;45:225-56. https://doi.org/10.1016/bs.enz.2019.08.003.

71. Jia Z, Liming Y, Ren Z, Wu L, Wang J, Guo J, et al. Delicate structural coordination of the severe acute respiratory syndrome coronavirus Nsp13 upon ATP hydrolysis. Nucleic Acids Res. 2019;47: $6538-50$

72. Thursz M. Iron, haemochromatosis and thalassaemia as risk factors for fibrosis in hepatitis C virus infection. Gut. 2007;56(5): 613-4. https://doi.org/10.1136/gut.2006.113076.

73. Galli A, Svegliati-Baroni G, Ceni E, Milani S, Ridolfi F, Salzano R, et al. Oxidative stress stimulates proliferation and invasiveness of hepatic stellate cells via a MMP2-mediated mechanism. Hepatology. 2005;41(5):1074-84. https://doi.org/10.1002/hep.20683.

74. Kaufmann SH, McMichael AJ. Annulling a dangerous liaison: vaccination strategies against AIDS and tuberculosis. Nat Med. 2005;11(4 Suppl):S33-44. https://doi.org/10.1038/nm1221.

75. Haider BA, Spiegelman D, Hertzmark E, Sando D, Duggan C, Makubi A, et al. Anemia, iron deficiency, and Iron supplementation in relation to mortality among HIV-infected patients receiving highly active antiretroviral therapy in Tanzania. Am J Trop Med Hyg. 2019;100(6):1512-20. https://doi.org/10.4269/ajtmh.18-0096.

76. Liu W, Zhang S, Nekhai S, Liu S. Depriving Iron supply to the virus represents a promising adjuvant therapeutic against viral survival. Curr Clin Microbiol Rep. 2020;20:1-7. https://doi.org/ 10.1007/s40588-020-00140-w.

77. Rigamonti L, Ariotti S, Losana G, Gradini R, Russo MA, Jouanguy E, et al. Surface expression of the IFN-gamma R2 chain is regulated by intracellular trafficking in human T lymphocytes. J Immunol. 2000;164:201-7.

78. Weiss G, Goossen B, Doppler W, Fuchs D, Pantopoulos K, Werner-Felmayer G, et al. Translational regulation via ironresponsive elements by the nitric oxide/NO-synthase pathway. EMBO J. 1993;12:3651-7.

79. Brock JH, Mulero V. Cellular and molecular aspects of iron and immune function. Proc Nutr Soc. 2000;59:537-40.

80. Regis G, Bosticardo M, Conti L, De Angelis S, Boselli D, Tomaino B, et al. Iron regulates T-lymphocyte sensitivity to the IFN-gamma/STAT1 signaling pathway in vitro and in vivo. Blood. 2005;105:3214-21.

81. Wang H, Yang P, Liu K, Guo F, Zhang Y, Zhang G, et al. SARS coronavirus entry into host cells through a novel clathrin- and caveolaeindependent endocytic pathway. Cell Res. 2008;18:290-301.

82. Merad M, Martin JC. Pathological inflammation in patients with COVID-19: a key role for monocytes and macrophages. Nat Rev Immunol. 2020;20:355-62. https://doi.org/10.1038/s41577-0200331-4. 
83. Lachmann G, Knaak C, von Haefen C, Paeschke N, Meisel C, Nyvlt $\mathrm{P}$, et al. Diagnostic biomarkers for adult haemophagocytic lymphohistiocytosis in critically ill patients (HEMICU): a prospective observational study protocol. BMJ Open. 2019;9:e032695.

84. Møller HJ. Soluble CD163. Scand J Clin Lab Inv. 2012;72:1-13.

85. Vishwanath P, Prashant A, Nataraj SM, Kotekar N, Doddamani P. Can soluble CD163 predict outcome of patients with acute respiratory distress from mechanical ventilation? A pilot study. Indian J Crit Care Med. 2013;17:355-8.

86. Crayne CB, Albeituni S, Nichols KE, Cron RQ. The immunology of macrophage activation syndrome. Front Immunol. 2019;10:119.

87. Schaer D, Schleiffenbaum B, Kurrer M, Imhof A, Bächli E, Fehr J, et al. Soluble hemoglobin-haptoglobin scavenger receptor CD163 as a lineage-specific marker in the reactive hemophagocytic syndrome. Eur J Haematol. 2005;74:6-10.

88. Behrens EM, Beukelman T, Paessler M, Cron RQ. Occult macrophage activation syndrome in patients with systemic juvenile idiopathic arthritis. J Rheumatol. 2007;34:1133-8.

89. Sakumura N, Shimizu M, Mizuta M, Inoue N, Nakagishi Y, Yachie A. Soluble CD163, a unique biomarker to evaluate the disease activity, exhibits macrophage activation in systemic juvenile idiopathic arthritis. Cytokine. 2018;110:459-65.

90. Colafrancesco S, Priori R, Alessandri C, Astorri E, Perricone C, Blank $\mathrm{M}$, et al. sCD163 in AOSD, a biomarker for macrophage activation related to hyperferritinemia. Immunol Res. 2014;60:177-83.

91. Nishino A, Katsumata Y, Kawasumi H, Hirahara S, Kawaguchi Y, Yamanaka H. Usefulness of soluble CD163 as a biomarker for macrophage activation syndrome associated with systemic lupus erythematosus. Lupus. 2019;28:986-94.

92. Gao Z, Wang Y, Wang J, Zhang J, Wang Z. Soluble ST2 and CD163 as potential biomarkers to differentiate primary hemophagocytic lymphohistiocytosis from macrophage activation syndrome. Mediterr J Hematol Infect Dis. 2019;11:e2019008.

93. Shimizu M, Mizuta M, Okamoto N, Yasumi T, Iwata N, Umebayashi H, et al. Tocilizumab modifies clinical and laboratory features of macrophage activation syndrome complicating systemic juvenile idiopathic arthritis. Pediatric Rheumatol Online J. 2020;18:2.

94. Isaacs JD, Harari O, Kobold U, Lee JS, Bernasconi C. Effect of tocilizumab on haematological markers implicates interleukin-6 signalling in the anaemia of rheumatoid arthritis. Athritis Res Ther. 2013;15:R204.

95. Schulert GS, Minoia F, Bohnsack J, Cron RQ, Hashad S, KonE'Paut I, et al. Effect of biologic therapy on clinical and laboratory features of macrophage activation syndrome associated with systemic juvenile idiopathic arthritis. Arthritis Care Res. 2018;70:409-19.

96. Hershko C, Link G, Cabantchik I. Pathophysiology of iron overload. Ann N Y Acad Sci. 1998;850:191-201.

97. Le Lan C, Loréal O, Cohen T, et al. Redox active plasma iron inC282Y/C282Y hemochromatosis. Blood. 2005;105(11):4527-31.

98. Temraz S, Santini V, Musallam K, Taher A. Iron overload and chelation therapy in myelodysplastic syndromes. Crit Rev Oncol Hematol. 2014 Jul;91(1):64-73. https://doi.org/10.1016/j. critrevonc.2014.01.006.

99. Traoré HN, Meyer D. The effect of iron overload on in vitro HIV1 infection. J Clin Virol. 2004;(Suppl 1):S92-8.

100. van Asbeck BS, Georgiou NA, van der Bruggen T, Oudshoorn M, Nottet HS, Marx JJ. Anti-HIV effect of iron chelators: different mechanisms involved. J Clin Virol. 2001;20:141-7.

101. Georgiou NA, van der Bruggen T, Oudshoorn M, Nottet HS, Marx JJ, van Asbeck BS. Inhibition of human immunodeficiency virus type 1 replication in human mononuclear blood cells by the iron chelators deferoxamine, deferiprone, and bleomycin. J Infect Dis. 2000;181:484-90.

102. Romeo AM, Christen L, Niles EG, Kosman DJ. Intracellular chelation of iron by bipyridyl inhibits DNA virus replication: ribonucleotide reductase maturation as a probe of intracellular iron pools. J Biol Chem. 2001;276:24301-8.

103. Crowe WE, Maglova LM, Ponka P, Russell JM. Human cytomegalovirus-induced host cell enlargement is iron dependent. Am J Physiol Cell Physiol. 2004;287:C1023-30.

104. Bayraktar Y, Koseoglu T, Somner C, Kayhan B, Temizer A, Uzunalimoglu B, et al. The use of deferoxamine infusions to enhance the response rate to interferon-alpha treatment of chronic viral hepatitis B. J Viral Hepat. 1996;3:129-35.

105. Mateos F, González C, Dominguez C, Losa JE, Jimenez A, PérezArellano JL. Elevated non-transferrin bound iron in the lungs of patients with Pneumocystis carinii pneumonia. J Inf Secur. 1999;38:18-21.

106. Arantes JM, Francisco AF, de Abreu Vieira PM, Silva M, Araújo MSS, de Carvalho AT, et al. Trypanosoma cruzi: desferrioxamine decreases mortality and parasitemia in infected mice through a trypanostatic effect. Exp Parasitol. 2011;128:401-8.

107. Lehmann C, Islam S, Jarosch S, Zhou J, Hoskin D, Greenshields A, et al. The utility of iron chelators in the management of inflammatory disorders. Mediat Inflamm. 2015;2015:516740.

108. Visseren FLJ, Verkerk MSA, van der Bruggen T, Marx JJM, van Asbeck BS, Diepersloot RJA. Iron chelation and hydroxyl radical scavenging reduce the inflammatory response of endothelial cells after infection with chlamydia pneumoniae or influenza A. Eur J Clin Investig. 2002;32(Suppl 1):84-90.

109. Kazmierski WM, Wolberg G, Wilson JG, Smith SR, Williams DS, Thorp HH, et al. Iron chelates bind nitric oxide and decrease mortality in an experimental model of septic shock. Proc Natl Acad Sci U S A. 1996;93:9138-41

110. Wang S, Liu C, Pan S, Miao Q, Xue J, Xun J, et al. Deferoxamine attenuates lipopolysaccharide-induced inflammatory responses and protects against endotoxic shock in mice. Biochem Biophys Res Commun. 2015;465:305-11.

111. Adams PC. Chelation therapy for secondary iron overload: is the primary effect less iron or less liver fibrosis? Gastroenterology. 2011;141:1142-3.

112. Adel N, Mantawy EM, El-Sherbiny DA, El-Demerdash E. Iron chelation by deferasirox confers protection against concanavalin A-induced liver fibrosis: a mechanistic approach. Toxicol Appl Pharmacol. 2019;382:114748.

113. Mohammed A, Abd Al Haleem EN, El-Bakly WM, ElDemerdash E. Deferoxamine alleviates liver fibrosis induced by CCl4 in rats. Clin Exp Pharmacol Physiol. 2016;43:760-8.

114. Darwish SF, El-Bakly WM, El-Naga RN, Awad AS, ElDemerdash E. Antifibrotic mechanism of deferoxamine in concanavalin A induced-liver fibrosis: impact on interferon therapy. Biochem Pharmacol. 2015;98:231-42.

115. Sobbe A, Bridle KR, Jaskowski L, de Guzman CE, Santrampurwala N, Clouston AD, et al. Inconsistent hepatic antifibrotic effects with the iron chelator deferasirox. J Gastroenterol Hepatol. 2015;30:638-45.

116. Tamura K, Uneda K, Azushima K, Wakui H, Haruhara K. Possible therapeutic impact of the iron chelation on renal fibrosis. Hypertens Res. 2015;38:455-6.

117. Ikeda Y, Ozono I, Tajima S, Imao M, Horinouchi Y, IzawaIshizawa $Y$, et al. Iron chelation by deferoxamine prevents renal interstitial fibrosis in mice with unilateral ureteral obstruction. PLoS One. 2014;9:e89355. 
118. Li LF, Huang CC, Liu YY, Lin HC, Kao KC, Yang CT, et al. Hydroxyethyl starch reduces high stretch ventilation-augmented lung injury via vascular endothelial growth factor. Transl Res. 2011;157:293-305.

119. Huang LT, Chou HC, Wang LF, Chen CM. Tissue plasminogen activator attenuates ventilator-induced lung injury in rats. Acta Pharmacol Sin. 2012;33:991-7.

120. Zhu W, Huang Y, Ye Y, Wang Y. Deferoxamine preconditioning ameliorates mechanical ventilation-induced lung injury in rat model via ROS in alveolar macrophages: a randomized controlled study. BMC Anesthesiol. 2018;18:116.
121. Perricone C, Triggianese $\mathrm{P}$, Bartoloni E, Cafaro G, Bonifacio AF, Bursi R, et al. The anti-viral facet of anti-rheumatic drugs: lessons from COVID-19. J Autoimmun. 2020;111:102468. https://doi. org/10.1016/j.jaut.2020.102468.

122. Shoenfeld Y. Corona (COVID-19) time musings: our involvement in COVID-19 pathogenesis, diagnosis, treatment and vaccine planning. Autoimmun Rev. 2020;19(6):102538. https://doi.org/ 10.1016/j.autrev.2020.102538.

Publisher's note Springer Nature remains neutral with regard to jurisdictional claims in published maps and institutional affiliations. 